\title{
KONZERVATORSKO-RESTAURATORSKI RADOVI NA PORTRETU FRANJE II. (I.) HABSBURŠKO-LOTARINŠKKOG IZ GRADSKOG MUZEJA VARAŽDIN
}

Slika Franje II. (I.) Habsburškog dio je serije velikih portreta Habsburgovaca iz fundusa Gradskog Muzeja Varaždin. $U$ želji da se portret Franje II. (I.) Habsburškog izloži na izložbi Varaždin pod krunom Habsburgovaca, trebalo ju je restaurirati zbog velike i raznorodne količine oštećenja, a i mogućnosti stvaranja novih. Saniranje oštećenja slikanog sloja koji je bio uzdignut i vrlo krhak, bio je vrlo složen i zahtjevan posao. Slika je konsolidirana in situ da bi se mogla dopremiti u radionicu Hrvatskog restauratorskog zavoda. Konzervatorsko-restauratorski radovi izvedeni su tijekom 2015. godine te je slika u listopadu iste godine vraćena u Varaždin i izložena na izložbi „Varaždin pod krunom Habsburgovaca".

Suradnici tijekom konzervatorsko-restauratorskih radova: Marija Kalmeta, Nena Meter Kiseljak, Slobodan Radić, Tanja Rihtar, Tanja Karakaš. Stolarski radovi: Dragutin Furdi. Fotografije: Ljubo Gamulin, Nikolina Oštarijašs. 


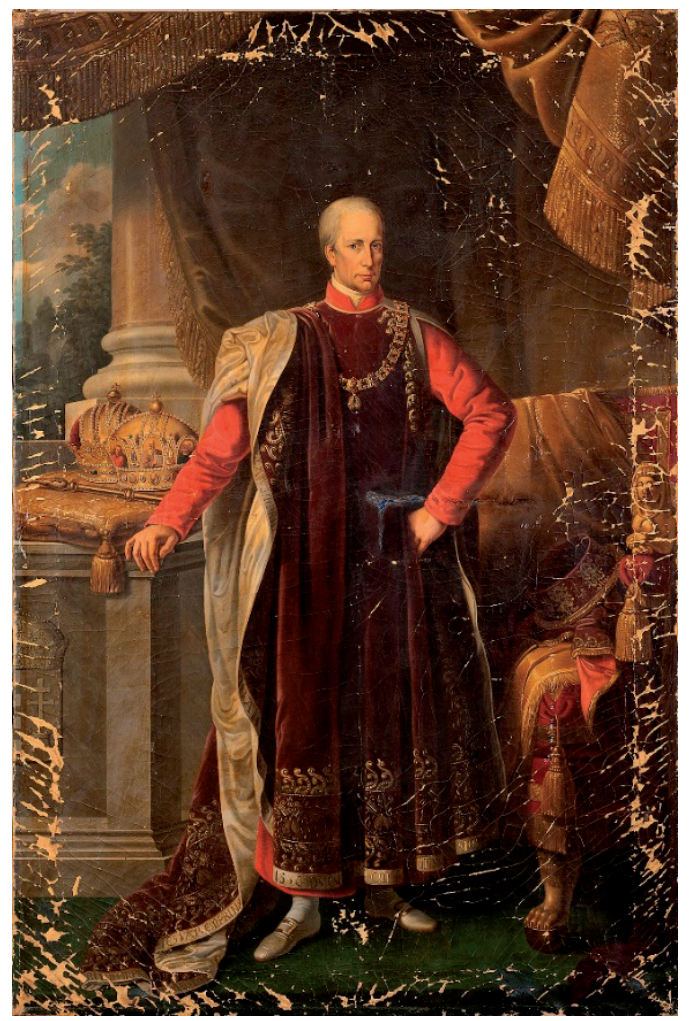

Slika 1. Stanje slike prije radova

\section{POJAŠNJENJE POVIJESNIH ČINJENICA VEZANIH UZ IME CARA I KRALJA FRANJE II. I FRANJE I.}

Carica i kraljica Marija Terezija, koja je vladala od 1740. do 1780. godine udala se za Franju Stjepana Lotarinškog (izvorno: Franz Stephan Lothringen). On je 1745. proglašen njemačko-rimskim carem i suvladarom Marije Terezije. Kao suvladar uzima ime car Franjo I. te s njim započinje vladarska dinastija HabsburgLothringen čiji je on utemeljitelj.

Nakon smrti oca Leopolda II. 1792. godine (sina Marije Terezije), krunom Svetog Rimskog Carstva² okrunjen je njegov sin Franjo, kao Franjo II. Habsbur-

2 Sveto Rimsko Carstvo (Sacrum Romanum Imperium) uspostavljeno je u 10. st. Za vrijeme cara Otona I. Obuhvaćalo je različite zemlje srednje Europe. Smatralo se nasljednikom Rimskog Carstva, od sredine 12. stoljeća nosi ime Sveto Rimsko Carstvo, a od sredine 16. st. zove se Sveto Rimsko Carstvo njemačkog naroda. 
ško - Lotarinški (u originalu Franz II. Habsburg Lothringen). Razlog tome je što je njegov djed, muž i suvladar Marije Terezije (njegove bake) bio okrunjen za cara Franju I.

Kao car Svetog Rimskog carstva njemačkog naroda, u čijem su sastavu bile mnoge zemlje (poput Austrije, dijela Njemačke, Nizozemske itd.), Franjo II.(I.) vladao je od 1792. do 1806. godine. Zbog poraza u nekoliko ratova protiv Francuske i na čelu s Napoleonom, izgubio je dijelove teritorija svoje carevine. Pod pritiskom Napoleona i uspostave mira s njim 1804. godine Franjo II. proglasio je Austrijsko Carstvo, a 1806. godine Napoleon ukida Sveto Rimsko Carstvo njemačkog naroda. Nestankom Rimskog Carstva car Franjo II.(I.) odrekao se carskog naslova. Proglasio se carem Austrijskog Carstva kao car Franjo I. i vladao je do smrti 1835. godine. On se smatra posljednjim carem Svetog Rimskog Carstva i jedini vladar koji je za života držao dvije carske titule (u periodu od 1804.-1806.). Uz titulu austrijskog cara Franjo I. bio je i ugarski, hrvatski i češki kralj od 1792. do 1835. godine i austrijski nadvojvoda.

\section{OPIS SLIKE}

Portret Franje II. (I.) spada u devet velikih portreta Habsburških vladara u vlasništvu Varaždinskog muzeja. Dimenzije slike kao i poze u kojima su slikani habsburški vladari naglašavali su njihov značaj. Slika prikazuje cijelu figuru Franje II.(I.) Habsburga u stojećem položaju u prostoru carske palače namještene klasicističkim pokućstvom. Stoji u laganom iskoraku, desnom rukom oslonjen na mramorni postament dok se lijevom oslanja o bok. Odjeven je u svečani ornatpropisano svečano odijelo visokodostojnika i ceremonijalni ogrtač vitezova Reda zlatnog runa od dugačkog plašta tamnocrvenog baršuna izvezen zlatovezom. Plašt je podstavljen bijelom svilom. Ispod plašta vladar je odjeven u grimiznu haljinu, na nogama nosi bijele niske cipele sa zlatnom kopčom. Rubni dijelovi ornata ukrašeni su francuskim tekstom: je l'ay emprins (usuđujem se) ${ }^{3}$. Car oko vrata nosi veliku ogrlicu - oznaku čina i dostojanstva prestižnog Reda zlatnog runa, ${ }^{4}$ u obliku lanca s obješenom stiliziranom janjećom kožom. Uz njega su vladarski simboli, žezlo i krune. Naglašeno je zanimanje za dekorativne elemente, detalje odjeće, bogatu draperiju. S desna na mramornom postamentu s reljefno izvedenim mađarskim grbom, koji se tek djelomično vidi, nalaze se na žutosme-

3 Mirjana DUČAKIJEVIĆ, Varaždin pod krunom Habsburgovaca, katalog izložbe, Gradski Muzej Varaždin, za katalošku jedinicu, 2015., 160.-161.

4 Španjolski Red zlatnog runa jedan je od najprestižnijih i najekskluzivnijih redova na svijetu uspostavljen 1430. godine. 
đem jastuku vladarski simboli: kruna austrijskih careva i kruna sv. Stjepana (bliže ruci vladara) te carsko žezlo. Krunom sv. Stjepana (na kojoj su prikazani likovi apostola), car Franjo II. Habsburško-Lotarinški okrunjen je za kralja Ugarske i Hrvatske. S lijeve strane, na brokatnom naslonjaču sa zlatnim lavljim šapama i sfingom odložena je kapa ukrašena zlatnim vezom i pozamanterijom. Iznad visi dio brokatne zavjese.

Lažna arhitektonska kulisa i idealan pejzaž u pozadini doprinose svečanosti atmosfere kojom se naglašava značaj portretiranog lika. U donjem desnom kutu slike nazire se signatura: Johan (?) pinx: Vienna 182 (?).

\section{O AUTORU SLIKE}

Franjo II.(I.) Habsburški za vrijeme svoje vladavine tri je puta posjetio Varaždin pa su stoga Varaždinci za trajnu uspomenu na ta tri zapažena posjeta naručili njegov portret. Prvi postav povijesnih portreta bio je 1923. godine i tada je slika Franje II.(I.) bila izložena u Gradskom muzeju Varaždin u prostoriji velikih portreta. Krešimir Filić, prvi ravnatelj Muzeja i autor kataloga prvog vodiča Gradskog muzeja iz 1943. godine, kao autora slike navodi Johanna Suesa (pinxit Viennae 1828.). ${ }^{5}$ Zbog velikih oštećenja prije restauracije signatura autora nazirala se u donjem desnom kutu. Nakon sanacije slikanog sloja na tom dijelu vidljiv je dio signature i datacija Johan,(?) pinx: Vienna 182?. Sanacijom oštećenja u dijelu potpisa dolazi se do saznanja da dijelovi potpisa ne odgovaraju potpisu Johannu Suesa kojeg Filić navodi kao autora. Ime autora je u potpunosti čitljivo i odgovara imenu navedenog autora.

Čitljivi dijelovi prezimena ne odgovaraju atribuiranom autoru. Prema sačuvanim ostacima slova prezimena u signaturi, vidljiv je donji dio prvog i drugog slova, treće slovo je u potpunosti čitljivo, četvrto djelomično, zadnja dva slova su čitljiva. Drugi red je potpuno čitljiv osim zadnje brojke u godini koja je djelomično čitljiva. Istraživanjima komparativnog materijala nailazi se na bečkog slikara Johanna Hermanna (Beč, 10. travnja 1794. - Beč, 5. veljače 1880.) koji je živio u Beču i djelovao kao portretist i slikar povijesnih prizora. ${ }^{6}$ Potpis Johanna Hermanna na slici „Junges mädchen mit myrthenkranz und perlenkette “7 , („Mlada djevojka s vijencem od mirte i bisernom ogrlicom“), ulje na platnu, 1823. godine

5 Krešimir FILIĆ, U spomen 20- godišnjice postojanja "Varaždinskog muzealnoga družtva", Varaždinski muzej, 1943., 52.

6 Benezit, Dictionary of Artists, Volume 6 Gemignani-Herring, 2006., 1441.

7 https://www.hampel-auctions.com/a/Johann-Herrmann-1794-Wien-1880.html?a=85\&s=254\&id=9 1647\&g=Gemaelde-19-20-Jhdt (27. svibnja 2019.) 
odgovara potpisu koji se nalazi na portretu Franje II.(I.) Habsburškog. Uočena je velika sličnost u načinu pisanja slova J, o, h, a, n, potom pinx i brojke 182 .U prilog atribuciji slike Franje II.(I) Johannu Hermannu osim velike podudarnosti u potpisu postoji i sličnost u načinu slikanja. Na obje slike može se uvidjeti slikareva posvećenost u slikanju detalja (draperija, čipka, krune, vjenčić u kosi, biseri), načinu slikanja pejzaža te blagi poluprofil kod oba portreta. Zelena pozadina na kojoj su potpisi slikana je slično u vrlo tankom nanosu zelene boje. Način slikanja i potpis se podudaraju čime se otvara mogućnost daljnjim istraživanjima i utvrđivanju točne atribucije slike Franje II. (I.) Habsburškog.

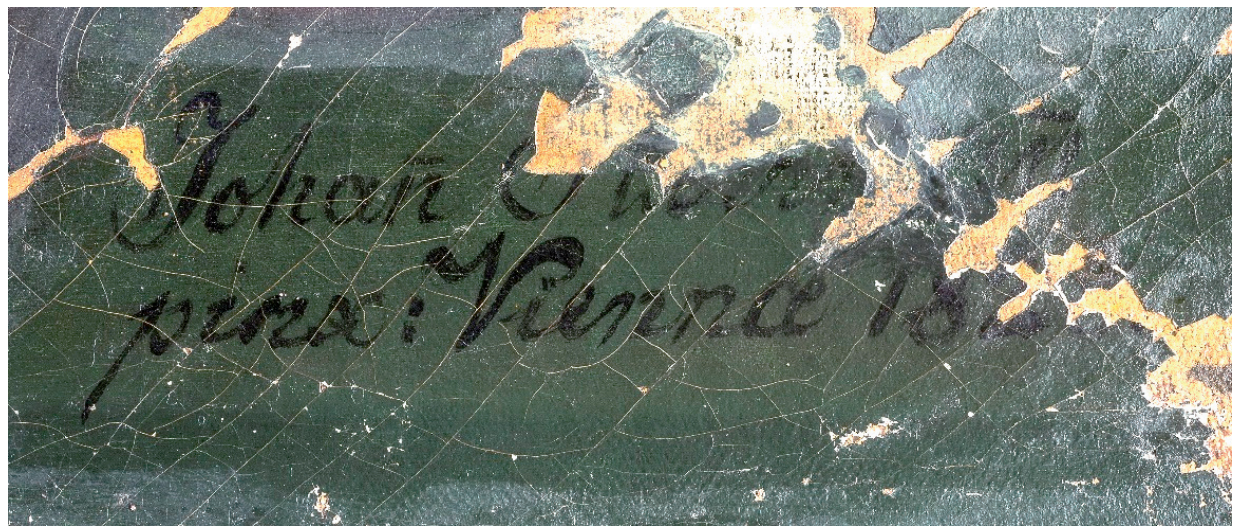

Slika 2. Signatura nakon čišćenja slikanog sloja

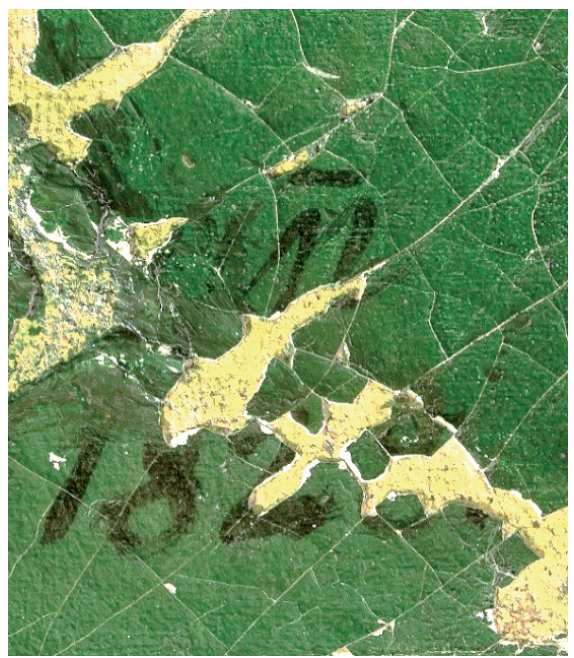

Slika 3. Dio signature u kojem se nazire vjerojatno slovo (a) i vidljivo slovo $n$ kao zadnje u potpisu , u drugom redu može se isčitati godina 182, a zadnja brojka je 3 ili 8 ? 
RENATA MAJCAN ŠRAGALJ: Konzervatorsko-restauratorski radovi na portretu Franje II. (I.) ...

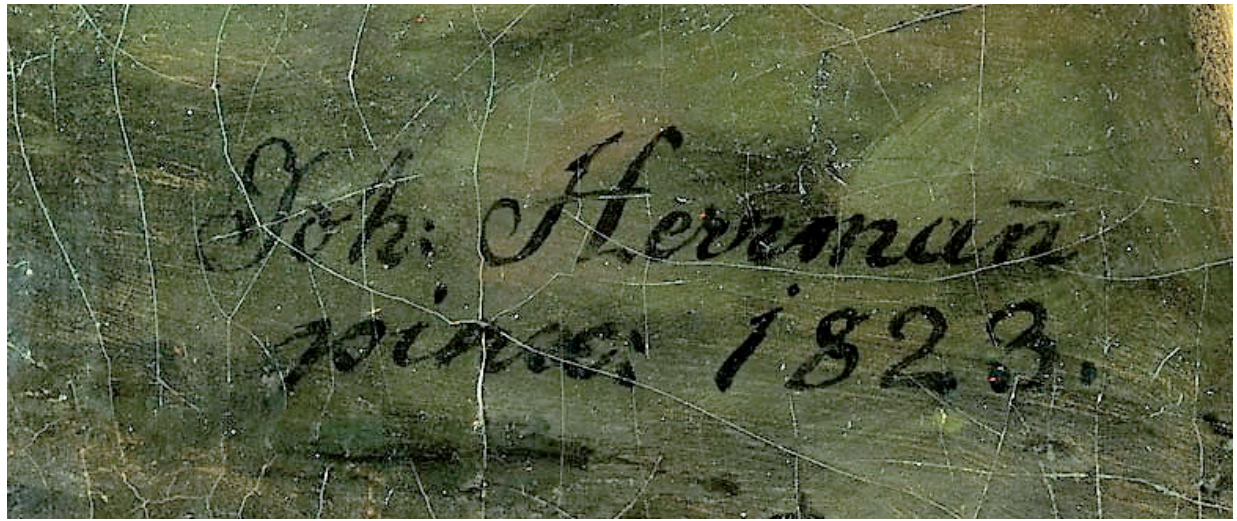

Slika 4. Signatura slikara Johanna Hermanna koja odgovara potpisu sa slike Franje II.(I.)

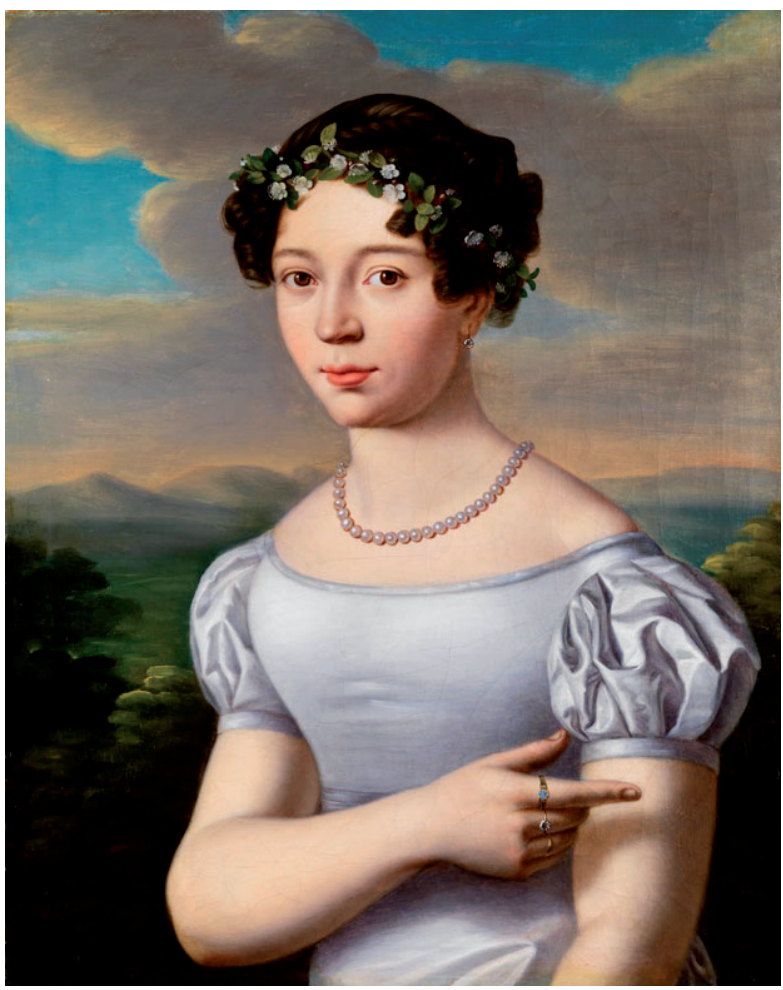

Slika 5. Mlada djevojka s vijencem od mirte i bisernom ogrlicom 


\section{OPIS ZATEČENOG STANJA SLIKE}

Slika Franje II. (I.) Habsburškog ulje je na platnu dimenzija 233 x $153 \mathrm{~cm}$. Nosilac slike je tanko, gusto laneno platno fine strukture, tkano iz jednog komada. Na poleđini platna škrobnim ljepilom bilo je zalijepljeno osam zakrpa. Na površini slike bila su vidljiva mnogobrojna oštećenja slikanog sloja koji je bio iskrakeliran, naboran, uzdignut i mjestimično odvojen od osnove i nosioca. Krakelire (prema franc. Craquelure) su sitne napukline, pukotine koje nastaju na slikanom sloju uslijed starenja slikanog sloja ili promjene mikroklimatskih uvjeta. Uz rubne dijelove platna jače su izražena oštećenja na kojima nedostaje slikani sloj i podloga. Cijelom površinom slike prisutne su dugačke uzdignute krakelire. Uzdignuća su veličine 2 do $3 \mathrm{~mm}$ koje se na pojedinim mjestima dodiruju, na nekima se preklapaju, a ponegdje su spojena. Uzdignuti dijelovi slikanog sloja izrazito su tvrdi, ali ujedno vrlo krhki i vrlo lomljivi. Zbog opisanih oštećenja umjetnina je bila izrazito osjetljiva za rukovanje. Pretpostavlja se da je do te vrste oštećenja došlo uslijed skupljanja nosioca i podloge (platna) pod utjecajem promjene mikroklimatskih uvjeta u kojima se slika nalazila. Podokvir se blago ocrtavao na licu slike te su na tim područjima oštećenja najveća. U središnjem dijelu slike, uz lijevu ruku stojećeg lika vladara, nalazilo se horizontalno oštećenje (poderotina) dužine tridesetak centimetara sa starim zakitima i retušima. Na tom dijelu vidljivi su i dijelovi neadekvatne zakrpe s poleđine koja je stvarala deformaciju na slici, a ispod kojeg je vidljiva zakrpa s preslikom. Neadekvatna zakrpa stvara deformaciju na slici, a na tom su mjestu vidljivi loše izvedeni stari zakiti i retuši. Stari su zakiti vidljivi i u donjem dijelu slike gdje su naneseni direktno na nosioc bez podloge, u izrazito debelom sloju, prekrivajući i dio originalnog slikanog sloja. Slika je prekrivena slojem prljavštine, a lak je neravnomjerno požutio. Mjestimično, a osobito u gornjem lijevom dijelu, vidljivo je curenje laka, vjerojatno nastalo prilikom njegovog nanošenja. 
RENATA MAJCAN ŠRAGALJ: Konzervatorsko-restauratorski radovi na portretu Franje II. (I.) ...

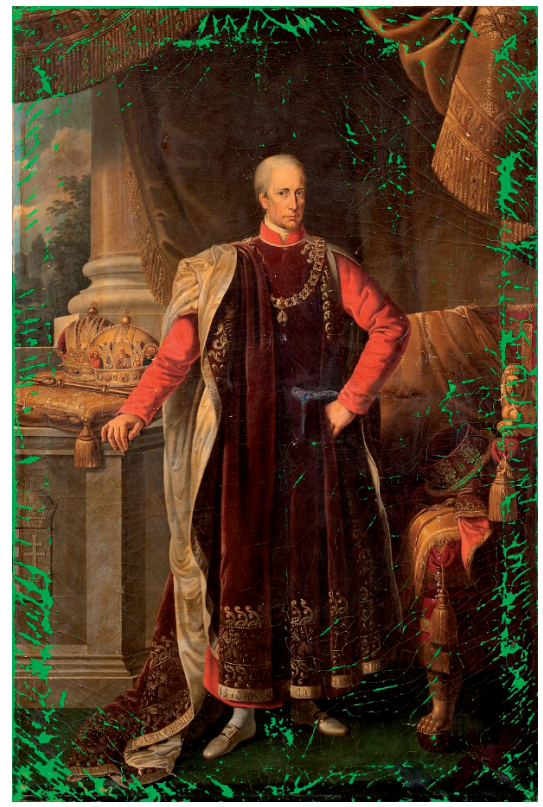

Slika 6. Grafički prikaz oštećenja na slici

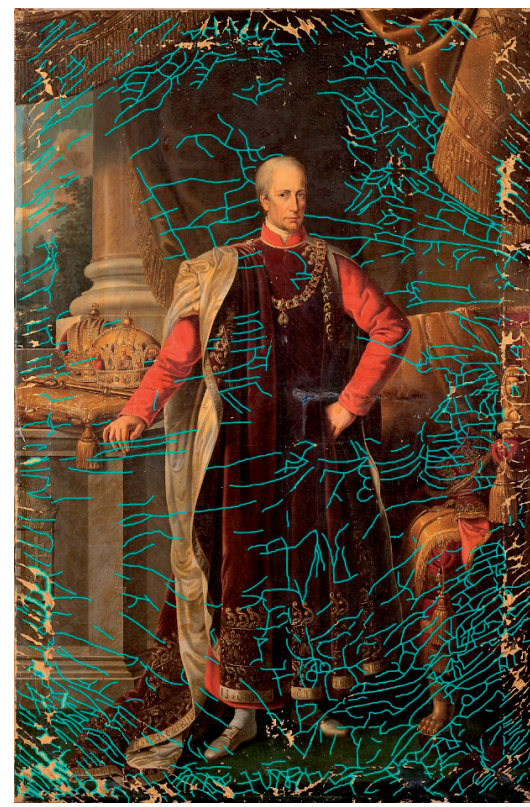

Slika 7. Grafički prikaz uzdignutih krakelira 
Radovi Zavoda za znanstveni rad HAZU Varaždin; br. 30, 2019, str. 241-257

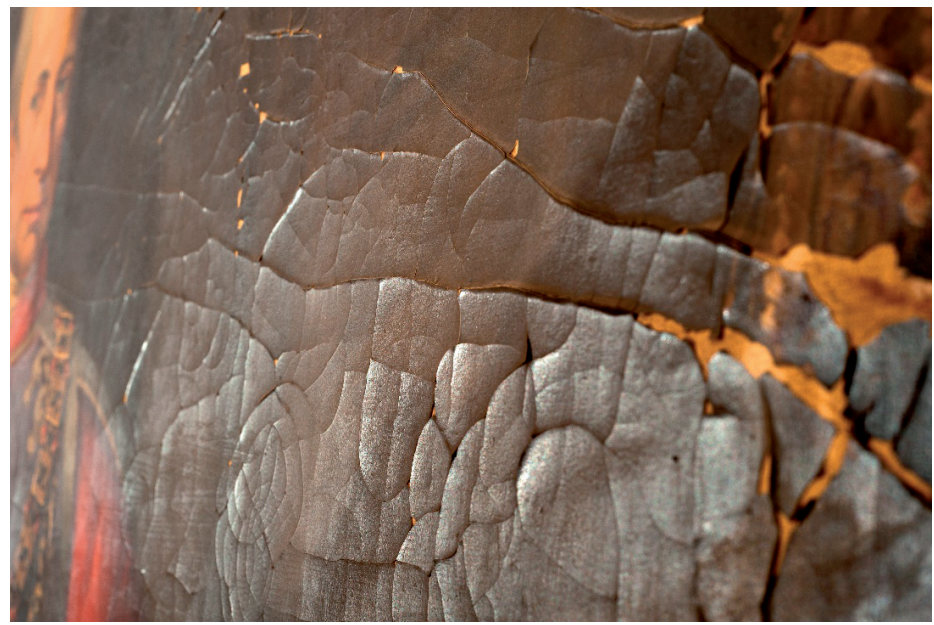

Slika 8. Detalj s vidljivim odvajanjem slikanog sloja i osnove od nosioca, koso svjetlo

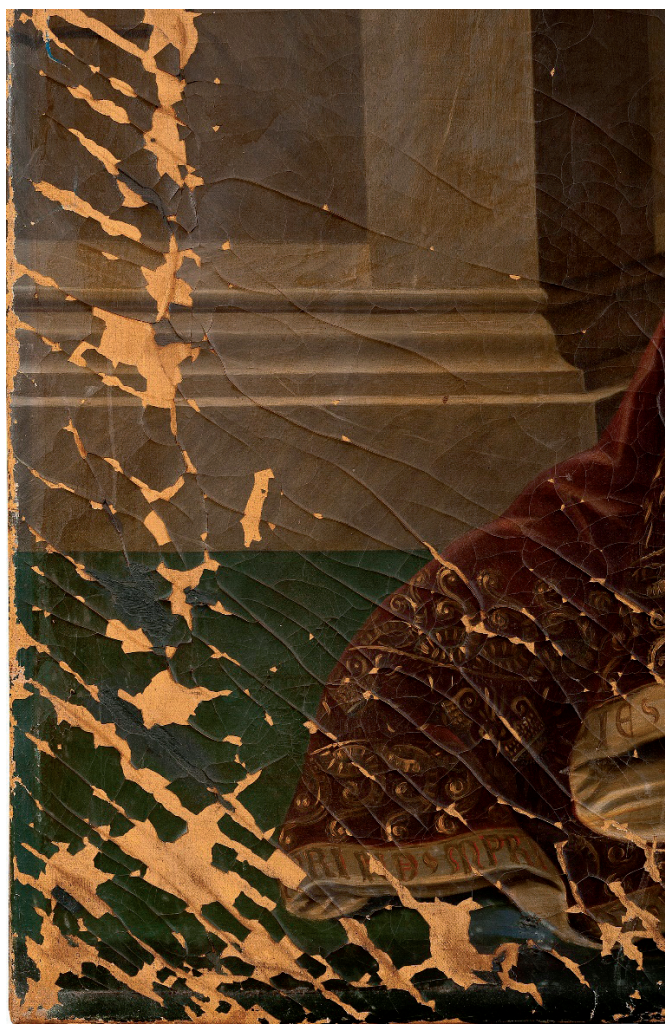

Slika 9. Dijelovi slikanog sloja i podloge koji nedostaju 


\section{IZVEDENI KONZERVATORSKO-RESTAURATORSKI RADOVI}

Zbog velikih oštećenja i krhkosti slikanog sloja koji je bio uzdignut, sliku je bilo neophodno konsolidirati in situ. Nakon transporta slike u HRZ ponovno je nanesen konsolidant. Na poleđinu platna uz rubove, zalijepljene su trake reverzibilnim lijepilom. Izabrane trake su od sintetičkog platna. Potom je slika napeta na pomoćni podokvir većih dimenzija kako bi se omogućilo sigurno rukovanje slikom i spriječilo stvaranje novih oštećenja.

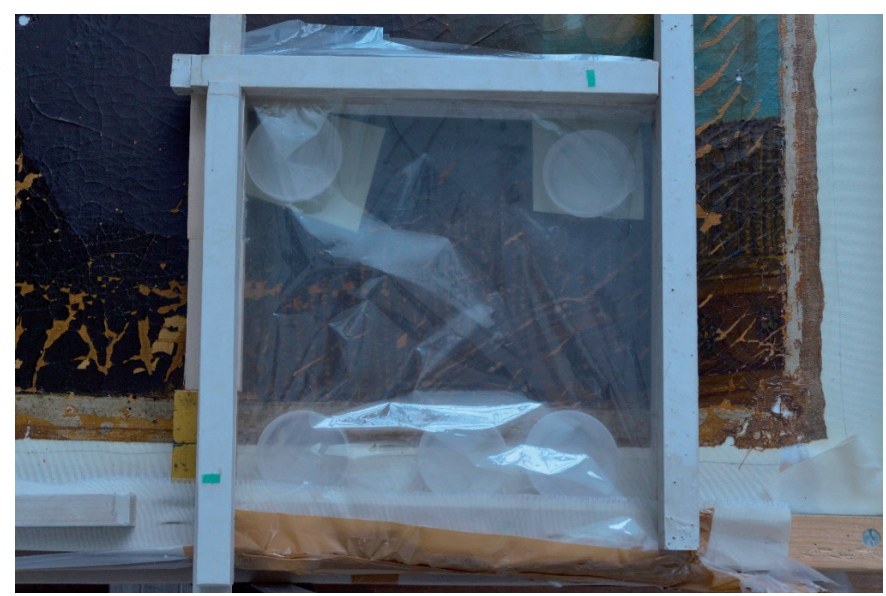

Slika 10. Mala improvizirana komora

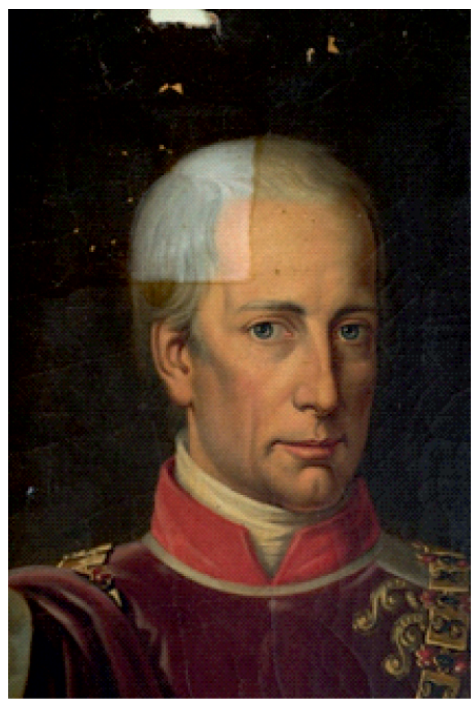

Slika 11. Detalj sondiranja slikanog sloja 


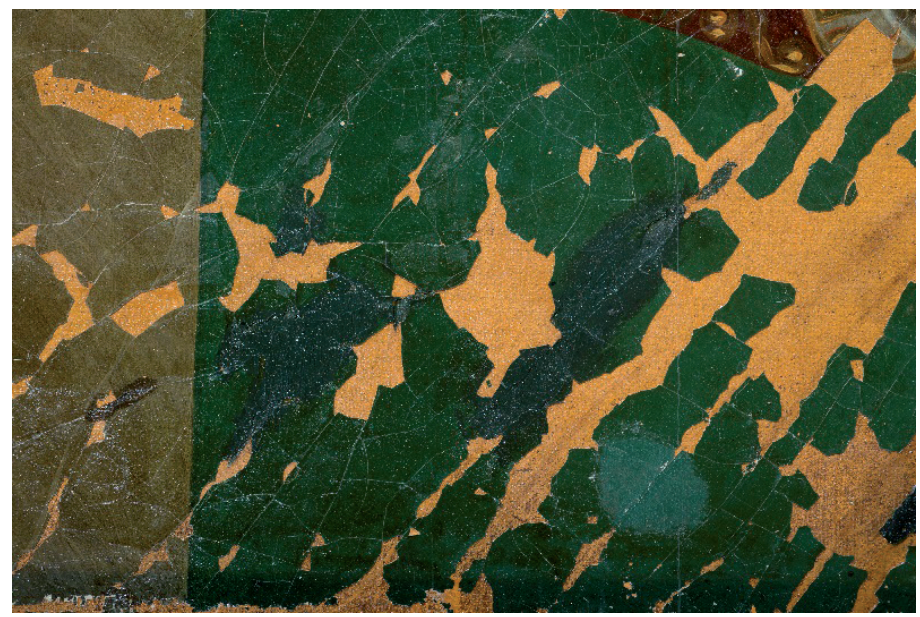

Slika 12. Detalj slike na kojem su stari retuši direktno naneseni na original

Potom se pristupilo složenom postupku omekšavanja i spuštanja slikanog sloja. U improviziranoj komori veličine slike, izrađenoj pomoću silikonskih utega i termostabilne folije, djelovanjem alkoholnih para omekšavao se uzdignuti slikani sloj. Unutar improvizirane komore postavljene su posudice sa alkoholom. Djelovanjem alkoholnih para postepeno se zatezalo pomoćni podokvir i time se djelovalo na minimalno rastezanje platna. Potom su napravljene improvizirane komore manjih dimenzija u kojima je rezultat omekšavanja tvrdih uzdignuća s djelovanjem alkoholnih para bio pojačan. Isparavanjem alkoholnih para u hermetički zatvorenoj komori, slikani sloj je omekšavan dio po dio, a postupak više puta ponavljan. Nakon omekšavanja pojedinog dijela, krakelire su spuštane vrlo polako, najviše do $2 \mathrm{~cm}$ dužine odjednom s malom toplinskom peglicom kroz prozirnu termostabilnu foliju u svrhu kontrole. Potom su odmah optežavane i hlađene utezima manjih dimenzija. Omekšavanje pojedinih dijelova trajalo je 24 sata, a ponekad je postupak ponavljan i nekoliko puta kako bi se dobili željeni rezultati. Djelovanjem alkoholnih para i konsolidanta površina je postajala ljepljiva i omekšana što je omogućilo lakše spuštanje sloja boje i podloge. Površina improvizirane komore nije smjela biti velika jer bi se dotokom zraka omekšani dio prebrzo stvrdnjavao. 


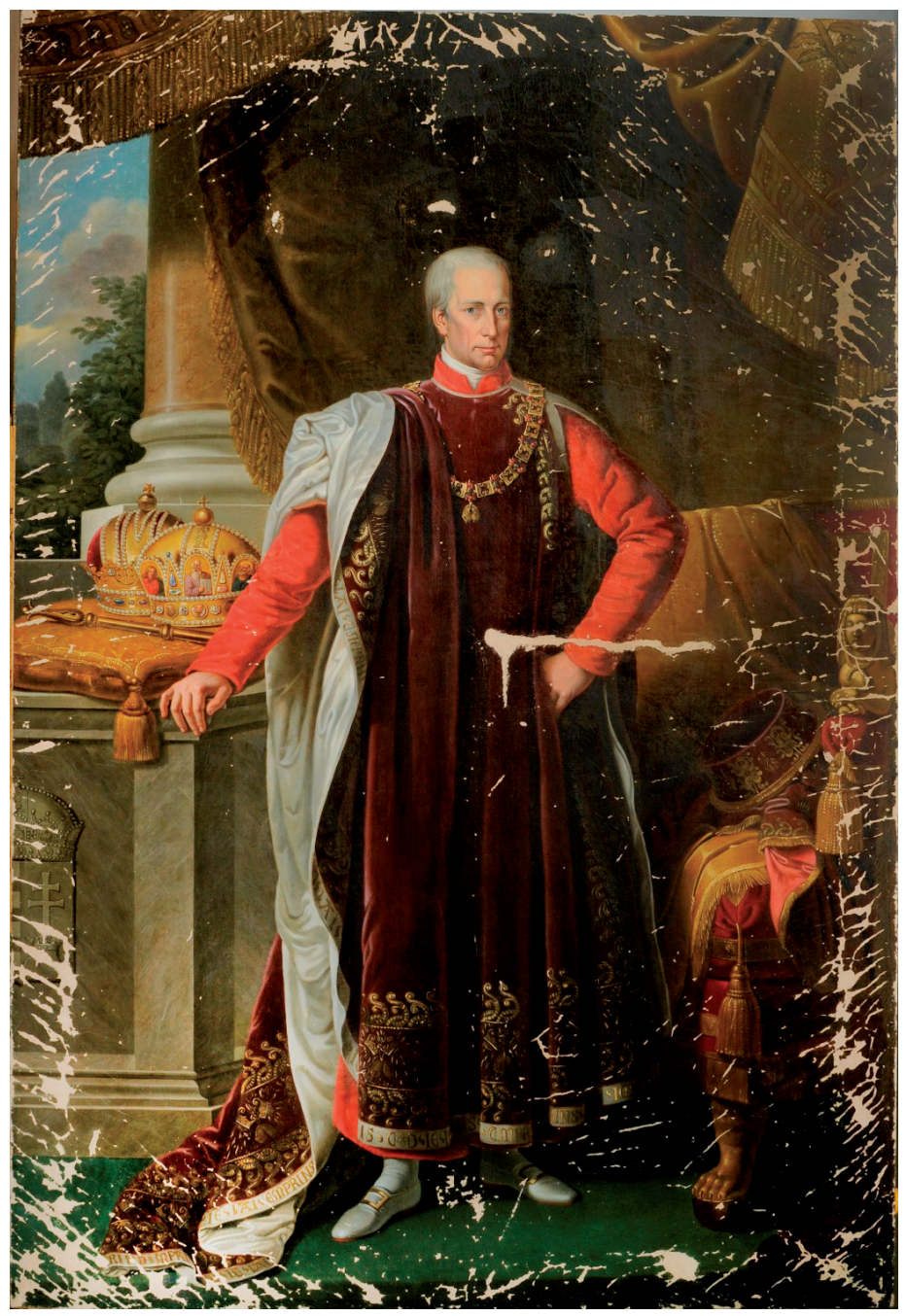

Slika 13. Stanje slike nakon kitanja

Nakon spuštanja krakelira slika je skinuta sa starog podokvira i okrenuta na lice s kojeg se uklonilo 8 starih platnenih zakrpa koje su bile nejednako zalijepljene škrobnim ljepilom. Područje ispod najveće zakrpe bilo je deformirano zbog starih zakita i preslika nanesenih preko originala i to u vrlo debelom sloju. Taj sloj je bio sastavljen od debelog tvrdog kita koji je služio kao nosilac i osnova. S obzirom da je stvarao deformaciju na platnu i slikanom sloju, uklonjen je mehaničkim putem. 
Nakon uklanjanja starih zakrpa i neadekvatnih kitova, pristupilo se probama čišćenja slikanog sloja. Izabrana je otopina alkohola koja je dala zadovoljavajuće rezultate u probama čišćenja. Uklonjeni su prljavština i debeli sloj požutjelog laka. Potom se pristupilo uklanjanju ostataka starih zakita i retuša koji su uklonjeni kemijskim i mehaničkim putem jer su bili prilično tvrdi i prekrivali su dio originalnog slikanog sloja. Nakon dočišćavanja slika je izravnata na toplinskom vakuum stolu.

Nakon sanacije jedne veće i nekoliko manjih perforacija, nedostajući dijelovi nosioca nadomješteni su novim umecima ranije impregniranog lanenog platna, sličnog tkanja i strukture kao originalno iskrojenog po obliku oštećenja. Potom je originalno platno podloženo novim lanenim i zalijepljeno rentaulažnim ljepiIom na toplinskom vakuum stolu. Postojeća oštećenja su zakitana akrilnim kitom uz dodatak pigmenta. Tekstura novih rekonstrukcija kita imitira okolnu teksturu. Nakon ponovnog ravnanja na toplinskom vakuum stolu slika je napeta na novoizrađeni drveni, klinasti podokvir. Prva faza retuša, podlaganje gvaš bojama, izvedena je u svijetlijim tonovima. Nakon sloja izolacionog laka, završni retuš izveden je lazurnim smolnim bojama. Završno lakiranje izvedeno je kombinacijom mat i sjajnog laka.

Na ukrasnom okviru napravljena je stolarska sanacija oštećenja na drvenom nosiocu. Nedostajući dijelovi podloge rekonstruirani su u kredi, a nakon nanošenja sloja bolusa, retuširano je zlatom u prahu i zlatnim listićima. 
RENATA MAJCAN ŠRAGALJ: Konzervatorsko-restauratorski radovi na portretu Franje II. (I.) ...

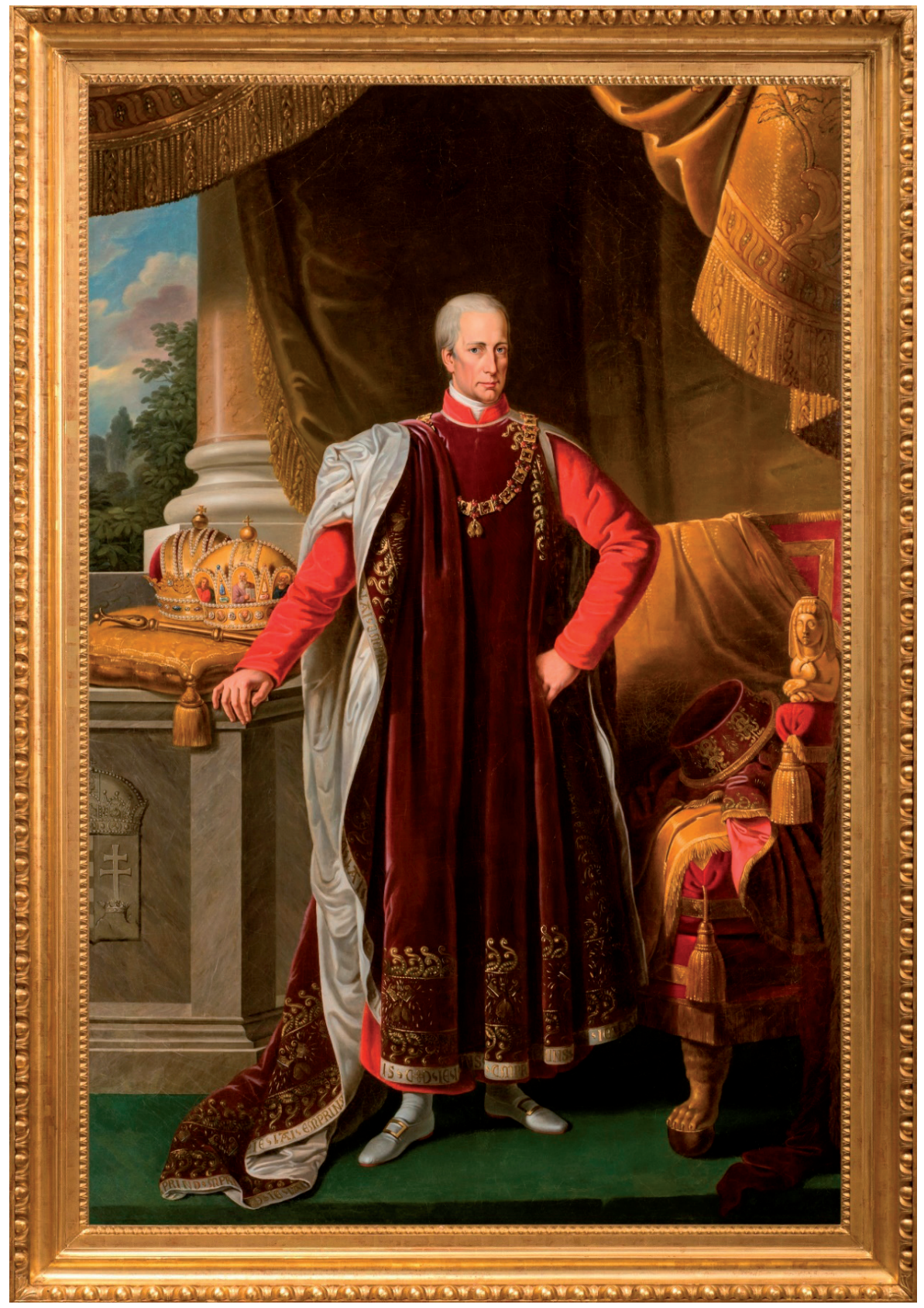

Slika 14. Slika nakon radova u ukrasnom okviru 


\section{LITERATURA I IZVOR I}

1/ BENEZIT, Dictionary of Artists, Volume 6, Gemignani-Herring, 2006.

2/ Des Kaisers Rock : Uniform und Mode am österreichischen Kaiserhof 1800 bis 1918 : katalog izložbe. Österreichische Galerie Belvedere, Dvorac Halbturn, Austrija, 1989.

3/ Des Kaisers teure Kleider : Uniform und Mode am Wiener Hof - Festroben und Ornate, Hufuniformen und Livréen vom frühen 18. Jahrhundert bis 1918. Beč, Kunsthistorisches Museum, 2000.

4/ Hrvatski biografski leksikon, http://hbl.lzmk.hr/clanak.aspx?id=42

5/ https://www.hampel-auctions.com/a/Johann-Herrmann-1794-Wien-1880. html? $a=85 \& s=254 \& i d=91647 \& g=G e m a e l d e-19-20-J h d t$ (27. 5. 2019.)

6/ Krešimir FILIĆ, Varaždinski muzej, U spomen 20-godišnjice postojanja varaždinskog muzealnog društva, 1943.

7/ Mirjana DUČAKIJEVIĆ, Varaždin pod krunom Habsburgovaca, katalog izložbe, Gradski Muzej Varaždin, 2015.

8/ Portreti iz fundusa muzeja, PPMHP, Rijeka, 1999. 


\section{SAŽETAK}

KONZERVATORSKO-RESTAURATORSKI RADOVI NA PORTRETU FRANJE II. (I.) HABSBURŠKO-LOTARINŠKOG IZ GRADSKOG MUZEJA VARAŽDIN

Pripremom izložbe Varaždin pod krunom Habsburgovaca, željelo se izložiti velike formate Habsburških vladara. Na slici Franje I. Habsburga koja se pripisuje bečkom slikaru Johannu Suesu trebalo je provesti cjeloviti i zahtjevne konzervatorsko-restauratorske radove kako bi se sliku moglo izložiti. Slika je početkom 2015. godine konsolidirana in situ te je dopremljena u HRZ na restauraciju. Saniranje oštećenja slikanog sloja bio je izuzetno složen i zahtjevan posao. Znatna su oštećenja slikanog sloja zatečena cijelom površinom platna u vidu brojnih krakelira, nabora, uzdignuća te odvajanja istih od osnove i nosioca. Krakelire su bile izrazito tvrde, ali ujedno vrlo lomljive. Pretpostavlja se da je do te vrste oštećenja došlo uslijed skupljanja nosioca i podloge (platna) pod utjecajem promjene mikroklimatskih uvjeta u kojima se slika nalazila. Pristupilo se složenom postupku omekšavanja i spuštanja slikanog sloja te prianjanja nosiocu. U malim improviziranim komorama, izrađenim pomoću silikonskih utega i termostabilne folije te djelovanjem alkoholnih para omekšavao se uzdignuti slikani sloj. Hermetički zatvorena komora uz isparavanje alkoholnih para omogućila je omekšavnje dio po dio, a postupak je više puta ponavljan. Nakon omekšavanja pojedinog dijela, krakelire su spuštane polako, najviše do $2 \mathrm{~cm}$ dužine odjednom s malom toplinskom peglicom kroz prozirnu termostabilnu foliju u svrhu kontrole. Potom su odmah optežavane i hlađene malim utezima. Spomenuti postupak dao je zadovoljavajuće rezultate te se nakon spuštenog i konsolidiranog slikanog sloja moglo nastaviti s daljnjom izvedbom konzervatorsko-restauratorskih radova koji su obuhvatili uklanjanje starih zakita, čišćenje slikanog sloja, sanaciju perforacija intarzijama, kitanje, retuš i lakiranje. ${ }^{8}$

Ključne riječi: Franjo II. (I.) Habsburški; Johann Hermann; krakelire; konzervatorsko-restauratorski radovi.

8 Voditeljica konzervatorsko-restauratorskih radova: Renata Majcan Šragalj. 


\section{SUMMARY}

\section{CONSERVATION AND RESTORATION WORKS ON THE PORTRAIT OF FRANCIS II (I) HABSBURG - LOTHRINGEN FROM VARAŽDIN CITY MUSEUM}

Preparing the exhibition Varaždin under the Habsburg crown, the objective was to display larger paintings of the Habsburg monarchs. On the painting of Francis II (I) atributed to the Vienese painter Johann Sues, complex and wholesome restoration works had to be undertaken in order to make the painting ready for displaying. The painting was consolidated in situ at the begining of 2015. and then transported to Zagreb to the Croatian Conservation Institute. Further consolidation of the damages in the paint layer was very complex and demanding. There were large damages of the paint layer all over the surface of the picture. They are consisted of a large number of craquelures, creases, flaking of the layers and loss of adherence to the canvas. The paint flakes and craquelures were highly brittle as well as thick and tough. It is asumed that this type of damage appeared due to the shrinking of canvas that occured because of unsuitable microclimate conditions surrounding the painting previously. Procedures were undertaken as to slowly and carefully soften the flakes and paint layer to adhere it back onto the canvas. Using small and improvised sort of chambers consisted of silicon weights and heat - proof foil the paint layer was softened by alcohol fumes one area at a time and the procedure was repeated several times. Once the paint layer was softened on an area of the painting, the craquelures were pushed down gently on the canvas with the help of a heating spatula and heat-proof foil, no more than $2 \mathrm{~cm}$ of paint layer at a time. Then these areas were cooled and small weights were placed on that surface. This kind of procedure proved to be satisfactory, with good results. Completing the procedure of consolidating the paint layer and securing its adherence to the canvas we could continue further conservation. It is consisted of cleaning the paint layer, removing old fillings, filling in the missing parts of canvas, filling in the damages on paint layers, retouching and varnishing.

Key Words: Francis II (I) Habsburg; Johann Hermann; craquelures; restoration works. 
